\title{
ASEAN Political Security Community (APSC) on Counter-terrorism: Roles and Obstacles
}

\author{
Faruq Arjuna Hendroy ${ }^{1}$
}

${ }^{1}$ Centre for the Middle East and Global Peace Studies, State Islamic University Syarif Hidayatullah, Indonesia, faruqarjuna@gmail.com

\begin{abstract}
Terrorism issue has been transforming into a worldwide concern. Southeast Asia is undoubtedly currently facing the similar issue. During Afghan war, Southeast Asia might be only known as "the exporters" of foreign militants to Afghanistan's conflict zone. Going into the $21^{\text {st }}$ century, Southeast Asia has, in turn, become the home base for terrorism itself to grow. Thus, ASEAN, as a regional body which shades Southeast Asia member states, responded to its emergence. ASEAN regarded terrorism a huge threat and paid extremely high attention to it through the release of ASEAN Convention on Counter Terrorism (ACCT). Moreover, ASEAN enhanced its commitment as regional body by composing one pillar of cooperation in security called ASEAN Political Security Community (APSC). APSC helps to drive all ASEAN member states to commit onto ACCT by proceeding to the full ratification by each member state and applying the effective implementation in dealing with the issue. This paper examines APSC's role in combating terrorism within region and discusses its obstacles in implementing ACCT.
\end{abstract}

Keywords: ASEAN; ASEAN Political Security Community; Terrorism; ASEAN Convention on Counter-Terrorism; Non-Interference

\begin{abstract}
ABSTRAK
Terorisme telah bertransformasi menjadi perhatian dunia. Asia Tenggara, tidak diragukan lagi, saat ini tengah menghadapi isu yang sama. Selama perang Afghan, Asia Tenggara hanya dikenal sebagai "eksportir" militan asing ke dalam zona konflik Afghanistan. Memasuki abad ke-21, Asia Tenggara, dalam gilirannya, telah menjadi markas tempat terorisme itu bertumbuh. Sehingga, ASEAN, sebagai organisasi regional yang menaungi negara anggota Asia Tenggara, memberikan respon terhadap kemunculannya. ASEAN menganggap terorism sebagai ancaman yang besar dan benar-benar memperhatikan masala tersebut dengan menelurkan Asean Convention on Counter Terrorism (ACCT). Lebih jauh lagi, ASEAN meningkatkan komitmennya sebagai organisasi regional dengan mencetuskan satu pilar kerjasama di bidang keamanan yang disebut ASEAN Political Security Community (APSC). APSC berfungsi untuk mendorong semua negara anggota ASEAN untuk berkomitmen terhadap (penegakkan) ACCT dengan cara meratifikasi secara penuh dan menerapkan implementasi yang efektif dalam mengatasi isu tersebut. Artikel ini akan mengkaji peran APSC dalam memerangi terorisme di kawasan dan tantangan yang dihadapi (APSC) dalam mengimplementasikan ACCT.
\end{abstract}

Kata Kunci: ASEAN; ASEAN Political Security Community; Terorisme; ASEAN Convention on Counter-Terrorism; Non-Interfensi

\section{Introduction}

The 9/11 tragedy has become the common concern for international entities in the recent years. Its emergence in the twenty-first century completed the list of of the new threat of world, among others, infamously known as terrorism. Terrorism is associated with political violence driven by radical ideology and misinterpretation of certain religious teaching, accompanied by the act of terrorizing people, both civilians and noncivilians, in order to pursue the goal. Despite the fact that terrorists are the non-state actors, their 
power to pose threat to the state actors should not be undermined. The direct hit to the U.S. land in 9/11 strategy was an obvious evidence on how they couldn't be underestimated. Many attempts have been conducted since then, yet terrorism remains to flourish. Its recent massive and quick spread to any regions worlwide, including Southeast Asia, added by the U.S campaign for terrorism elimination, has successfully invited broader concern on the issue among ASEAN's leaders.

Terrorism is a transnational threat, given its "crossing-the-border" nature. This is because the terrorist groups gain the capability to plan and launch attacks in many states at the same time, operate across national boundaries, and manage funding and other kinds of support without being limited to the control of border-maintaining personnels. In Southeast Asia, there is a great fear that its plan of annexation of Malaysia, Southern Philippines, Singapore, Indonesia, Southern Thailand, and even North Australia, and transform them into one identity of Islamic State, leading to the disintegration of states already mentioned. Morever, the way the terrorist groups are choosing to realize their visions - mainly bombing absolutely endanger various sectors such as tourism, travel, economic development, and political stability. Such religious-based violence might also potentially severe religious harmony and trigger intolerance and suspicion among religious groups. ${ }^{1}$

With these all facts in mind, ASEAN is obviously threteaned by those groups. The fact that Southeast Asia states once focused more on challenges of nation building and regime security has been overlapped by the emerging nontraditional threats. This kind of new threat was mainly caused by more borderless states due to globalization era which allows people, money, information, and goods to travel. The object of this

${ }^{1}$ Amitav Acharya. ASEAN 2030: Challenges of Building a Mature Political and Security Community. ADBI Working Paper Series, 441, pp. 7. 2013. threat is no longer states nor regimes, but non-state actors like individuals and society. ${ }^{2}$ Terrorism has long been associated with this kind of threat and is now transforming into a common agenda for regional cooperation.

ASEAN has moved forward to deal with the issue. ASEAN member states have all agreed that terrorism was a tangible threat to plentiful aspects leading to an urgency to stop it from growing bigger. Many meetings, agreements, and cooperations have been attempted. The most updated collective commitment and cooperation have been crystallized through the launching of ASEAN Political Security Community (APSC), a vision fo safer ASEAN. So, this article will discuss ASEAN's long journey in pivotal effort to combat terrorism to the point that it initiates APSC. Then, it will also discuss APSC's contribution and obstacle in assisting ASEAN to combat terrorism in regional level.

\section{Methodology/Theory}

I use qualitative methodology in conducting this article. First, I determined a topic/problem that I would like to discuss in this paper, which is APSC's role and obstacles in countering regional terrorism. Second, I conducted literature review to ensure that no previous research discussing about APSC's role as the new security platform of ASEAN in countering terrorism was written, strengthening the updatedness and originality of this research. Third, I determined the research objective/purpose. Fourth, I collected secondary data from various books, journals, online articles, and online news. Fifth, I analyzed the data by reading and re-reading it carefully and reducing it to what is truly connected to the research, and then categorizing it based on each sub-theme of the research. Sixth, in case of difficulties in understanding the specific meaning of information

\footnotetext{
${ }^{2}$ Aileen Baviera. Preventing War: Building a Rules-Based Order: Challenges Facing ASEAN Political Security Community.ASEAN@ 50,4, pp. 10-11.2004.
} 
collected from the data, I read it for many times and made my own interpretation. Seventh, I wrote the result of my analysis.

I use Regional Security concept as the theoritical framework of this article. Regional Security dervies from Barry Buzan's view conceptualized in his book "Regions and Power: The Structure of International Security." The emergence of regional security was basically not separated from reflections to national and global security. When a state mostly focused on its own national security, it was deemed unsufficient and vulnerable since no single state is self-capable to encounter relational security dynamics. Besides, focusing solely on global security is way too broad, lack of tight integration, and more reflecting aspiration rather than reality. The increasing concern on regional security is more precise, as regional is the setting for national and global interplay and most actions to be implemented. In a detailed explanation, Buzan stated that regional security is the level where states and other units link together sufficiently and closely that their common security concerns can no be separated one another. The close security interdependence among the regional states was created by the common fear and aspiration of the separate actors. ${ }^{3}$

The end of the Cold War era marks the emergence of the new dynamics of security agenda in international system. The concept of security has changed into the new form following the shifting kind of threat. It is no longer about security among states - typically known as traditional security - identical with twentieth century. As the object of the new threat is the single individual, society, and globe - vulnerably regarded as the potential victims of threat - the term of non-traditional security emerged, and securing those victims is absolutely a must. For

${ }^{3}$ Barry Buzan and Ole Waever. Regional and Power: The Structure of International Security (pp. 43). Cambridge: Cambridge University Press. 2003. the first time in history, as Bertel Heurlin and Kristensen emphasized, there is a common awareness of the necessity to fight for the common sustainability and security. The world has predominantly been integrated, embracing various dimensions of globalization, transnastionalism, interdependence, and integration. ${ }^{4}$ This concept has pushed ASEAN to solidly possess regional security community, which is seeking to eliminate the new kind of threat such as terrorism.

According to Andrew Chau, there are three classifications of regional security community; 1) It starts with nascent form, in which states pursue the cooperation for the sake of their respectively national security. 2) Then it proceeds to the next stage, ascendant form, to formalize such cooperation into institution and organization, which results in deeper trust relationship between the cooperating parties. 3) The top stage is mature form. Once the cooperating parties has reached this stage, they start to willingly share value and identity as well as depend on each other within institution or organization framework to bring the true peace and stability into reality. ${ }^{5}$ Despite the increasing awareness of regional security importance, ASEAN has so far not reached the mature form, especially in regional counter-terrorism efforts, due to non-interference principle that is still strongly rooted to ASEAN's way and a few tendencies to act partially a couple of times.

\section{Terrorism in Southeast Asia}

After its big success to expel USSR from Afhganistan in the end of 1980s, Al-Qaeda, the leading terrorist group at the beginning of twenty first century, set the new agenda to expand its network to Southeast Asia. Some Al-Qaeda

\footnotetext{
${ }^{4}$ Bertel Heurlin and Kristensen. International Security.

Danish Institute of International Affairs, 2, pp. 3.

${ }^{5}$ Andrew Chau. Security Community and Southeast Asia: Australia, the US, and ASEAN Counter-Terror Strategy. Asian Survey 48, 4, pp. 628. 2008.
} 
members flew to Southeast Asia to build local cells by recruiting or cooperating with the indigenous militant group such as Jemaah Islamiyah (JI) and the Moro Islamic Liberation Font (MILF) for the sake of Al-Qaeda's global terror agenda. Both JI and MILF were supported with fund and military training to wage war against what they call as "infidels". This new network of Al-Qaeda plotted several attacks in Philippines and Indonesia and moved freely across Singapore, Malaysia, and Thailand. This marks the rise of terrorist activtity in Southeast Asia which Bush Administration called as the second front of global terrorism. ${ }^{6}$

Southeast Asia seems so attractive to AlQaeda for several reasons. Southeast Asia consists of biggest Muslim population which constitutes majority group in the region. Despite the statistical fact, Southeast Asia has been forming the good relations to the Western power, notably the US, which is declared by $\mathrm{Al}$ Qaeda as its eminent foe. Morever, in Singapore and Thailand, Israeli embassies were settled. Al Qaeda basically sought to remove their influence off Southeast Asia. In addition, in location where Muslims are minority, like South Thailand, South Philippines, and Poso of Central Sulawesi, they were oppressed and intimidated. Acting as the protector of the oppressed, Al Qaeda infiltrated to launch the attack on behalf of Muslim solidarities. Another reason could be the massive amount of ex-Afghan fighters. They are emotionally linked to Al-Qaeda members for having struggled together and fought hand in hand in Afghanistan. Such massive amount could help Al-Qaeda to magnify the possibility to succeed in targetting its foes in the region. $^{7}$

\footnotetext{
${ }^{6}$ Bruce Vaugh, Emma Chanlett-Avery, Richard Cronin, Mark Manyin, and Larry Niksch. Terrorism in Southeast Asia. Congressional Research Service, pp. 2-3. 2009.

${ }^{7}$ As'ad Said Ali. Al-Qaeda: Tinjauan Sosial-Politik, Ideologi, dan Sepak Terjangnya. LP3ES, pp. 195-196. 2014.
}

In fact, not all Southeast Asia states are infiltrated by Al-Qaeda and its cells. They were active ini Philippines with the main vision of confrontating the US interest, setting Philippines as the preparation base for World Trade Center (WTC) attack in 1993, and building paramilitary camp for its extended influence. Al-Qaeda was also active in Indonesia, as could be seen from the series of bombing targeting Western people. Al Qaeda was using its cell, Jammah Islamiyah of Indonesia, as the executor while Al Qaeda was providing the funding. Malaysia and Singapore were the next active target, for having warm relations to the West, viewed from the similarity of law and educational system. An attack to Singapore was plotted before 9/11 tragedy. The attack was finally aborted because Singapore's authority increased vigilance following the 9/11. Meanwhile Malaysia was relatively safe from terror, yet it was used by the militants as the rendezvous or transit point to plot the big-scale attacks. Al-Qaeda's activity was also ever found in Southern Thailand, assisting a few Pattani fighters. Due to the very limited number of radicalized Pattanian, Al-Qaeda was inclined to recruit cells from Indonesia and Malaysia. ${ }^{8}$

Terrorism activities in Southeast Asia keeps multiplying over the years. Since Al-Qaeda's influence has diminished in the recent time, its role is now replaced by the new emerging terrorist group, namely ISIS. Southeast Asia remains a target, despite the shifting of groups and vision priorities. ISIS has a military wing which consists of the pure Southeast Asia Malay-speaking militants called Katibah Nusantara and are based in Syria. Furthermore, ISIS central manages to strengthen its cells, interactions, and actions with the local terrorists. It spread the influence into Southeast Asia via internet publication which succesfully created and inspired the so-called home-grown terrorists. They never reach ISIS central but declare vows to the caliphate and

${ }^{8}$ Ibid, pp. 198-228 
always get prepared to sacrifice for its sake in the states they are currently living in. ${ }^{9}$ It is difficult to deny that the phenomenon of advanced technology is like a double-edged sword possessing both positive and negative impact at the same time.

\section{General Overview: Timetable of ASEAN Counter-terrorism Effort}

Although the terrorist activities began to appear in the early to mid 1990s, ASEAN leaders have not seriously considered them a prominent threat until the $9 / 11$ in 2001. ASEAN's response to the 9/11 was the symbol of political solidarity with the US. ASEAN expressed its support with a statement 'to use all necessary and available means to pursue, capture, and punish those responsible for the attack and to prevent additional attacks'. In December 2001, approximately two months after the 9/11 tragedy, ASEAN created a Declaration on Joint Action to Counter Terrorism which emphasized that all acts of terrorism are an attack on humanity and completely unjustifiable regardless of any motivations and a profound threat to international peace and stability. ${ }^{10}$ The declaration itself was identified as the first ever official movement of ASEAN in dealing with terrorism issue in regional and international realm.

What was created in 2001 is simply a joint declaration which is allocating ASEAN no specific measures on how to practically combat terrorism. As result, ASEAN could not basically forecast nor anticipate the next tragedy to come. This let happen the 2002 Bali bombing which killed more than 200 Australian tourists and a few local residents without any prior anticipation from Indonesia government. Following the tragic calamity, ASEAN was urged - by pressure of any parties - to design more specific measures to

${ }^{9}$ Badrus Sholeh. Dari JI Ke ISIS: Pemikiran Strategis dan Taktis Gerakan Terorisme di Asia. Jurnal Hubungan Internasional 5, 2, pp. 211. 2017.

${ }^{10}$ Jurgen Haacke. The ASEAN Regional Forum: From Dialogue to Practical Security Cooperation? Cambridge Review of International Affairs 22, 3, pp. 430. 2009. prevent, counter, and supress terrorism in the region through "Declaration on Terrorism" agenda by the $8^{\text {th }}$ ASEAN Summit of Phnom Penh. ASEAN sought to cooperate with and pleaded wide support from international community. ${ }^{11}$

More serious movements have been adopted by ASEAN since 2002 considering the fact that the terrorist continously posed the insecurity. In 2003, ASEAN arranged some prominent assemblies such as; 1) Workshop on combating terrorism for ASEAN police focusing on establishment of anti-terrorism task force, 2) Government legal officers program on antiterrorism focusing on the possibility of criminilizing the terrorists, harmonizing laws for terrorism cases in entire ASEAN, as well as the possibility for the creation of a firm operational convention on combating terrorism, and 3) the first ASEAN + 3 (Japan, China, RoK) consultation on terrorism. ${ }^{12}$ At the same time, ASEAN Security Community arouse under Bali Concord II declaration. In 2004, ASEAN arranged a ministerial meeting aimed at discussing transportation security from terrorist activity ${ }^{13}$, as well as the ASEAN - Australia partnership on security-check training. ${ }^{14}$

In 2007, ASEAN's commitment for counterterrorism effort reached its significant achievement through the creation of ASEAN

\footnotetext{
${ }^{11}$ Asean.org. (2002, November 3). Declaration on Terrorism by the $8^{\text {th }}$ Asean Summit in Phnom Penh. Retrieved from http://asean.org/?static_post=declaration-on-terrorism-by-the8th-asean-summit-phnom-penh-3-november-2002

12 S. Pushpanathan, Asean.org. (2003, August 20). ASEAN Efforts to Combat Terrorism. Retrieved from http://asean.org/?static_post=asean-efforts-to-combatterrorism-by-spushpanathan

${ }^{13}$ Asean.org (2004, February 5). Bali Regional Ministerial Meeting on Counter-terrorism: Co-Chairs Statement. Retrieved from http://asean.org/?static_post=bali-regionalministerial-meeting-on-counter-terrorism-bali-indonesia-5february-2004-co-chairs-statement ${ }^{14}$ Asean.org (2005, February, 2001) ASEAN Contribution to Regional Efforts in Counter-terrorism. Retrieved from http://asean.org/?static_post=asean-s-contribution-toregional-efforts-in-counter-terrorism
} 
Convention on Counter-Terrorism (ACCT). ACCT is basically the final outcome of prolonged debates and assemblies for years within ASEAN body. It serves as a reguler framework to prevent, counter, and surpress terrorism through the deepening cooperation. ${ }^{15}$ As mentioned above, the convention had been discussed since 2003, which means taking about 4 years to completely finalize it to what it is today. Referring to its name (read: convention), ACCT is remarkably distinct from its predecessors which format is merely declaration, workshop, discussion, and assembly. ACCT's status, regardless of the usefulness of its respectively predecessors, is more supreme because it adopts a 'legally binding' format. ACCT serves as today's solely product of ASEAN to refer to in counter-terrorism effort.

\section{ASEAN Political Security Community : Collective Vision and Driving Force to ACCT}

ASEAN Political Security Community (APSC) is a "vision for the future" envisioned by ASEAN leaders aiming to build ASEAN as a single community which provides life in peace, stability, and prosperity for everyone within the region. APSC is projected to emerge in 2020 as the aggregation of ASEAN Community, along with two other pillars; ASEAN Economic Community (AEC) and ASEAN Socio-Cultural Community (ASCC). ASEAN leaders took first step to begin the fulfillment of APSC through the declaration of Bali Concord II in 2003. APSC is expected to reinforce ASEAN's centrality - One ASEAN for all - and bear significant role as the driving force in charting the regional measure and mechanism. ${ }^{16}$

Serving as the ASEAN's vision for a safer life in the future, APSC encourages all ASEAN members to tackle all types of security issues that

\footnotetext{
15 Asean.org. (2013, January 22). ASEAN Convention on Counter Terrorsm Complete Ratification Process. Retrieved from http://asean.org/asean-convention-on-counter-terrorismcompletes-ratification-process/

${ }^{16}$ See APSC Blueprint (2009) : pp. 1
}

emerge in the region, ranging from traditional security issue such as the escalating dispute among member-states to the so-called non-traditional security issues which include terrorism. APSC's blueprint contains a special sub-theme that focuses to discuss actions or measures required to tackle non-traditional security issues. The sub-theme is divided again into two more specific points; 1) Combating transnational crimes and transboundary challenges, and 2) Counterterrorism effort, which is becoming the focus of this writing. ${ }^{17}$ In this case, APSC is the next manifestation of ASEAN's previous seriousness to combat terrorism within region.

Counter-terrorism effort embedded in APSC's blueprint strongly urges all ASEAN member-states to conduct the early ratification and full implementation of ACCT. Furthermore, it also urges the member states to accede and ratify the relevant international instruments (other than ACCT) which is deemed necessary and useful. ${ }^{18}$ APSC's role as the driving force to the ratification of ACCT symbolizes each state's commitment for a safer ASEAN from terrorism, and succesfully crystallizes such commitment into action soon after carrying out the ACCT ratification. As the status of ACCT itself is legally binding, then all measures, ways, and strategies directed by ACCT must be implemented by each member state without any exception.

ACCT comprises of 23 articles as a whole. In article 6, it clearly conveys the areas of cooperation which include the following measures; 1) Take the necessary steps to prevent the commission of terrorist acts, including by the provision of early warning to the other Parties through the exchange of information, 2) Prevent those who finance, plan, facilitate, or commit terrorist acts from using their respective territories for those purposes against the other Parties and/or the citizens of the other Parties, 3) Prevent and

\footnotetext{
${ }^{17}$ Ibid, pp. 13

${ }^{18}$ Ibid,
} 
suppress the financing of terrorist acts, 4) Prevent the movement of terrorists or terrorist groups by effective border control and controls on issuance of identity papers and travel documents, and through measures for preventing counterfeiting, forgery, or fraudulent use of identity papers and travel documents, 5) Promote capacity-building including trainings and technical cooperation and the holding of regional meeting, 6) Promote public awareness and participation in efforts to counter terrorism, as well as enhance inter-faith and intrafaith dialogue and dialogue among civilisations, 7) Enhance cross-border cooperation, 8) Enhance intelligence exchange and sharing of information, 9) Enhance existing cooperation towards developing regional databases under the purview of the relevant ASEAN bodies, 10) Strengthen capability and readiness to deal with chemical, biological, radiological, nuclear (CBRN) terrorism, cyber terrorism and any new forms of terrorism, 11) Undertake research and development on measures to counter terrorism, 12) Encourage the use of video conference or teleconference facilities for court proceedings, where appropriate, 13) Ensure that any person who participates in the financing, planning, preparation for the terrorist acts or in supporting terrorist acts is brought to justice. ${ }^{19}$

One interesting thing about this convention is laid down in article 3. It conveys that the parties should carry out the obligations, measure, or srategies embedded in the convention by maintaining the respect towards the principle of sovereignty and territorial integrity of states which become the parties to the convention. ${ }^{20}$ In other words, the principle of non-interference which has been identical with ASEAN's characteristics, remain the robust instrument that can not be separated from ASEAN, no matter what agreements or conventions are made. Yet, this inclusion of article 3 triggers critiques in the future.

${ }^{19}$ See ACCT manuscript : pp. 6-7

${ }^{20}$ See ACCT manuscrpit : pp. 5

\section{APSC: Roles and Obstacles}

APSC has been proven successful in driving all ASEAN member states to ratify ACCT and comply with it. ACCT was created in 2007. But it has not been ratified by the member states until APSC blueprint was released in 2009. Post 2009 release, each member state gradually ratified ACCT in the next years. Initially, there were only three states, namely Singapore, Thailand, and Philippines that ratified ACCT in 2010. One year later, Brunei Darussalam became the sixth state to ratify it, resulting in its entry into force for the first time. Indonesia did not ratifiy it until 2012 due to many considerations. In 2013, Malaysia became the tenth state to ratify it, ${ }^{21}$ which signifies that all ASEAN member states have already become the parties to ACCT owing to their commitment for a safer ASEAN under APSC from terrorism threat.

The implementation of ACCT under APSC spirit could be traced from the effort to combat terrorism in Philippines in 2011-2013. The terrorist acts in Philippines increase significantly within the range of 2011-2013. In detail, only 89 terrorism cases were found in 2011. Meanwhile in 2013, the total bounced to 652 cases. This makes Philippines the most vulnerable state to terrorist activities if compared to other ASEAN states. Those who took the full responsibility to the cases are the religious extremist groups such as Moro Islamic Liberation Front (MILF), Bangsamoro Islamic Freedom Fighter (BIFF), and Abu Sayyaf Group; all standing against Philippines official government for separatism. ${ }^{22}$ ASEAN helped Philippines with some measures derived from ACCT, such as; information and intelligence

\footnotetext{
${ }^{21}$ Nuclear Threat Initiatives. (2017, November 10). Association of Southeast Asia Nation. Retrieved from http://www.nti.org/learn/treaties-and-regimes/associationsoutheast-asian-nations-asean/

${ }^{22}$ Giuliani Agustha Namora. "Peran ASEAN Covention on Counter Terrorisme dalam Penangan Terorisme di Filipina Periode 2011-2013." Journal of International Relations UNDIP 2, 4, pp. 171-172. 2016.
} 
sharing, capacity building through training and technical cooperation, and routine meetings on strategy and action plans. Under the spirit of APSC to implement ACCT recommendation, Philippines does comply with all measures. ${ }^{23}$

Nevertheless, terrorism in Philippines demonstrated no sign of discontinuing, even with Phlippines's compliance with ACCT's recommended measures. In 2016-2017, world once again witnessed the threat to humanity in Marawi City of Philippines. The religious extremist groups which have declared loyalty to ISIS of the Middle East were responsible for the mass casualty. It was said that nearly US $\$ 600,000$ was transferred from the central ISIS of the Middle East to the Marawi militants. Actually, Southern Philippines has been the recent main target of the caliphate's development and struggle, due to the weakened ISIS central by global force. ${ }^{24}$

ISIS-affiliated groups launched attack in Marawi City which resulted in more than 1000 deaths. From May to July 2017, the official data have estimated that about 400,000 civilians from Marawi and the closest areas have been displaced. Another data from the National Disaster Reduction and Management Office (NDRRMO) specified that there are 5,055 families staying in 89 evacuation centers, while 98,846 others staying with distant relatives. ASEAN joined Marawi fight, although in the modest way. It provided humanitarian assistance such as deploying 600 family tents, 600 family kits, 3,000 personal hygiene kits, 600 kitchen sets, and four water filtration units. ${ }^{25}$ Despite the efforts, ASEAN is

\footnotetext{
${ }^{23}$ Ibid, pp. 176

${ }^{24}$ Max Walden in Asian Correspondent. (2017, November 27). Phlippines Most Affected by Terrorism in Asia Pacific. Retrieved from https://asiancorrespondent.com/2017/11/philippinesterrorism-asia-pacific/\#zvuwpiCiSRE28ZIP.97

${ }^{25}$ Prashanth Parameswaran in The Diplomat. (2017, July 25). ASEAN Deploys Terror Aid to Philippines Amid Marawi Crisis. Retrieved from https://thediplomat.com/2017/07/asean-deploys-terror-aid-tophilippines-amid-marawi-crisis/
}

still situated in some critiques. It is encouraged to act more than just providing the humanitarian assistance.

After watching all efforts recommended by ACCT did not work significantly to suppress the number of terrorist acts in Philippines which escalated year by year, and knowing the fact that ISIS central has set Philippines precisely and Southeast Asia generally as the second base of caliphate, the call for ACCT's revision is carried out by some critics. The fixed principle of noninterference, clearly found in article 3 when it is related to ACCT, is indeed ASEAN's unique way, yet hinders ASEAN member states to take the joint military option, like global actors did on successfully combating terrorism in the Middle East. Philippines itself is open for tactical and operational cooperation, however it never let the foreign troops of ASEAN member states to fire gun within its respected soil. ${ }^{26}$

The principle of non-interference is an anomaly amidst inclusive characteristics of regional cooperation. This makes ASEAN itself unique, yet possesses limitations here and there. This principle demonstrates that ASEAN member states prioritize sovereignty and national interest over inclusive cooperation and regional-level integration. This emphasizes again that states tend to be skeptical on treaties, agreements, and conventions, shoud all those elements violate their national interest. ${ }^{27}$ In its relation to ASEAN way, the principle of non-interference reflects how strong each member state's national interest is. Each ASEAN member state is not ready to take on the other ASEAN member states infiltrating its home with a bunch of military personnels, despite the fact that it is not the official government

\footnotetext{
${ }^{26}$ Chester Cabalza in The Diplomat (2017, August 19). Can ASEAN Work Together to Fight Regional Terrorism? Retrieved from https://thediplomat.com/2017/08/can-aseanwork-together-to-fight-regional-terrorism/

${ }^{27}$ Robert Jackson and Georg Sarensen. Introduction to International Relations: Theory and Approaches (pp. 81). United Kingdom: Oxford University Press. 2003.
} 
targetted. The existence of foreign military personnels is regarded an obvious threat to sovereignty which is deemed as the ultimate national interest of any states. Southeast Asia states seem to agree to tie themselves with both regional organization and convention, but not in a full bond. Even after the existence of sophisticated APSC, ASEAN remains the same old one. APSC which is claimed as a security provider for regional community (each individuals in region) does not accomodate the reconsideration of such principle of non-interference to step on further actions.

The proposal for joint military option was once attempted by Indonesia in a discussion of ASEAN forum. Indonesia urged joint military formation in order to strengthen regional's roles and mutual political trust among ASEAN members, as well as minimize international's interference with regional affairs. However, some ASEAN member-states stand against Indonesia's idea. Vietnam's representative thought the idea was still too early, then argued that political and military capabilities belonging to several states were not still sufficient for such regional cooperation. Singapore's representative also rejected the idea by stating that ASEAN was not a defence organization. Meanwhile, Thailand's representative asserted the idea as unnecessary for thinking that there were no conflicts in the region that truly urged ASEAN troops to make a move. ${ }^{28}$ When referring to Andrew Chau's three classifications of regional security community, it emphasizes ASEAN has not taken its mature form.

Borchers argued that a "sacrifice" is required. ASEAN member-states should have lowered their respectively degree of sovereignty to bring joint military option into realization. ASEAN leaders need to consider human security - which is becoming the target of terrorist activities - as

\footnotetext{
${ }^{28}$ Henning Borchers. ASEAN's Environmental Challenges and non-Traditional Security Cooperation: Toward a Regional Peace-keeping Force. Österreichische Zeitschrift für Südostasienwissenschaften, 7, 1, pp. 10. 2014.
}

important as state's sovereignty. The primacy of individual human right should also be on the top priority to secure, leading to the willingness of each states to diminish the principle of noninterference's influence. Still for Borchers, forming the joint military option is not bad at all. The formation means the willingness, readiness, and commitment for regional consolidation and mutual trust across ASEAN member - states to serve its community, securing them away from any kinds of potential threat. It is true that the principle of non-interference was a supreme norm keeping all ASEAN member-states together, according to some scholars and government officials. ${ }^{29}$ However, APSC is expected to drive each member state to go beyond the principle.

Morever, although all ASEAN member states have been aware of the rising terrorist acts and the existence of APSC drives their counter-terrorism commitment into ACCT ratification, APSC fails to coordinate all ASEAN member states to actively contribute. The varied threat level of terrorism each ASEAN member-state is facing and different military capablities are the reasons behind the hindered full contribution by all member states on counter-terrorism effort. States like Laos and Cambodia face less threat of terrorism and may not have well-prepared action. Meanwhile, states like Indonesia, Malaysia, Singapore, and Philippines face greater threat of terrorisme and enjoy more equipped and well-resourced forces to combat terrorism. The fact already proves that in Marawi crisis, for example, it is only Indonesia and Malaysia that contributed actively to help Philippines with some border intelligence sharing and patrols over troublesome Sulu Sea, since Marawi fighters - led by Abu Sayyaf - were also the active pirates in Sulu Sea. ${ }^{30}$

\footnotetext{
${ }^{29}$ Ibid, pp. 16

${ }^{30}$ Michael Hart. Asian Correspondent (2018, February 12). How Marawi Pushed ASEAN nations to Join Force Against Terrorism. Retrieved from https://asiancorrespondent.com/2018/02/marawi-pushed-
} 
Indonesia, Malaysia, and Philippines officially formed air patrol named Trilateral Air Patrol (TAP). TAP comprises of two aspects: joint air patrols with the presence of participating state's aircrew on joint aircraft and coordinated air patrols within their each borders. The first aspect of TAP was conducted regularly every month in turn by Malaysia on November, Philippines on December, Indonesia on January, and so on. ${ }^{31}$ Morever, the three states also launched Trilateral Maritime Patrol (TMP) to boost the security maintenance and stability guarantee. This air and maritime joint patrols were meant to stop acts of piracy as well as cut off the flow of foreign fighters into Marawi City. ${ }^{32}$ However, it needs to bear in mind that the nature of this patrol cooperation is trilateral which means only those with endangered national interest played the role, as they confront the potential threat near their borders (Troublesome Sulu Sea is located near Indonesia, Malaysia, and Philippines). This again emphasized the frequent absence of APSC as regional security body. The fact that states individually take on action seems evident. Meanwhile, other ASEAN member states remain passive as they do not confront the direct threat stimulating to join the move.

\section{Conclusion}

With APSC's current state, its vision to create a safer place across ASEAN is questionable. APSC should be set to get prepared for any worst

\footnotetext{
asean-nations-join-forces-tackle-

terrorism/\#tAz6iBv8ozCkHih6.97

${ }^{31}$ Mike Yeo. DefenceNews (2017, October 13). Malaysia, Indonesia and Philippines target ISIS in Trilateral Air Patrols. Retrieved from https://www.defensenews.com/naval/2017/10/13/malaysiaindonesia-and-philippines-target-isis-in-trilateral-air-patrols/

${ }^{32}$ Francis Chan. The Straits Times (2017, June 19). Indonesia, Malaysia Philippines Launch Joint Operations in Sulu Sea to Tacke Terrorism, Transnational Crimes. Retrieved from https://www.straitstimes.com/asia/indonesia-malaysia-andphilippines-launch-joint-operations-in-sulu-sea-to-tackleterrorism
}

scenario and with a bunch of alternatives including common military enforcement. One might argue the nature of terrorism is a "spreading power", since it moves from one place to another in order to erect its version of government. States like Laos and Cambodia might be relieved for currently less threat of terrorism. However, if the threat of terrorism was someday intensified in the two states, while their force capabilities remained wellresourced nor well-prepared, terrorism would easily flourish therein. APSC will respond, as usual, through ACCT implementation with training, intelligence sharing, and planning as well. However, since such measures were proven less-effective, the joint military option under ASEAN's fleet, with all ASEAN member-states delegating their troops to become ASEAN soldiers, should be an available alternative to cover Both Laos and Cambodia's lack of force capabilities. Thus, security for all communities within ASEAN is achievable. 
Public can't deny APSC's huge role so far in counter-terrorism effort. Its role as the driving force to the implementation of ACCT is somehow considered the ASEAN's highest achievement for indicating the sucessful encouragement for the member-state's commitment towards integration in security matters. Still and all, APSC can actually move forward from what it has already attempted to realizing a more direct-integrated combat. It can urge, or at least recommend, to revise ACCT by adding one article on the possibility for a joint military option for counter-terrorism and impetus for all member-states to comply with the revision. What seems so clear in the present time is as long as the principle of noninterference is still strongly rooted to ASEAN's DNA, it is unlikely to see the imminent revision.

\section{References}

Ali, As'ad Said. (2014). Al Qaeda: Tinjauan Sosial-Politik, Ideologi, dan Sepak Terjangnya. Jakarta: LP3ES.

ASEAN Secretariat. (2007). ASEAN Convention on Counter Terrorism (ACCT).

ASEAN Secretariat. (2009). ASEAN Poltical Security Community (APSC) Blueprint.

Asean.org. (2002). Declaration on Terrorism by the $8^{\text {th }}$ Asean Summit in Phnom Penh. http://asean.org/?static_post=declaration-onterrorism-by-the-8th-asean-summit-phnompenh-3-november-2002 [Accessed May, 25, 2018]

Asean.org. (2003). ASEAN Efforts to Combat Terrorism.

http://asean.org/?static_post=asean-effortsto-combat-terrorism-by-spushpanathan [Accessed May, 2, 2018]

Asean.org. (2004). Bali Regional Ministerial Meeting on Counter-terrorism: Co-Chairs
Statement. http://asean.org/?static_post=baliregional-ministerial-meeting-on-counterterrorism-bali-indonesia-5-february-2004-cochairs-statement [Acessed May, 26, 2018]

Asean.org. (2005). ASEAN Contribution to Regional Efforts in Counter-terrorism. http://asean.org/?static_post=asean-scontribution-to-regional-efforts-in-counterterrorism. [Accessed May, 26, 2018]

Asean.org. (2013). ASEAN Convention on Counter Terrorsm Complete Ratification Process. http://asean.org/asean-conventionon-counter-terrorism-completes-ratificationprocess/ [Accessed May, 26, 2018]

Baviera, Aileen. (2004). Preventing War: Building a Rules-Based Order: Challenges Facing ASEAN Political-Security Community.ASEAN@ 50, 4, 1-18

Borchers, Henning. (2014). ASEAN's Environmental Challenges and nonTraditional Security Cooperation: Toward a Regional Peace-keeping Force. Österreichische Zeitschrift für Südostasienwissenschaften, 7, 1-17. doi: 10.14764/10.ASEAS-2014.1-2

Buzan, Barry and Ole Waever. (2003). Regional and Power: The Structure of International Security. Cambridge: Cambridge University Press.

Cabalza, Chester. (2017). Can ASEAN Work Together to Fight Regional Terrorism? https://thediplomat.com/2017/08/can-aseanwork-together-to-fight-regional-terrorism/. [Accessed June, 2, 2018]

Chan, Francis. (2017). Indonesia, Malaysia Philippines Launch Joint Operations in Sulu Sea to Tacke Terrorism, Transnational Crimes. https://www.straitstimes.com/asia/indonesia- 
malaysia-and-philippines-launch-jointoperations-in-sulu-sea-to-tackle-terrorism.

[Accessed July, 25, 2018]

Chau, Andrew. (2008). Security Community and Southeast Asia: Australia, the US, and ASEAN Counter-Terror Strategy. Asian Survey 48, (4), 626-649. doi: 10.1525/as.2008.48.4.626

Haacke, Jurgen. (2009). The ASEAN Regional Forum: From Dialogue to Practical Security Cooperation? Cambridge Review of International Affairs 22, (3), 427-449. doi: $10.1080 / 09557570903104057$

Hart, Michael. (2018). How Marawi Pushed ASEAN nations to Join Force Against Terrorism.

https://asiancorrespondent.com/2018/02/mara wi-pushed-asean-nations-join-forces-tackleterrorism/\#tAz6iBv8ozCkHih6.97 [Accessed June, 2, 2018]

Heurlin, Bertel and Kristensen. International Security. Danish Institute of International Affairs 2, 1-11

Jackson, Robert and Georg Sarensen. (2013). Introduction to International Relations: Theory and Approaches. United Kingdom: Oxord University Press.

Namora, Giuliani Agustha. (2016). Peran ASEAN Covention on Counter Terrorisme dalam Penangan Terorisme di Filipina Periode 2011-2013. Journal of International Relations UNDIP 2, (4), 170-179

Nuclear Threat Iniatives. (2017). Association of Southeast Asia Nation, http://www.nti.org/learn/treaties-andregimes/association-southeast-asian-nationsasean/ [Accessed May, 28, 2018]
Parameswaran, Prashanth. (2017). ASEAN Deploys Terror Aid to Philippines Amid Marawi Crisis. https://thediplomat.com/2017/07/aseandeploys-terror-aid-to-philippines-amidmarawi-crisis/. [Accessed June, 1, 2018]

Sholeh, Badrus. (2017). Dari JI ke ISIS: Pemikiran Strategis dan Taktis Gerakan Terorisme di Asia. Jurnal Hubungan Internasional, 5, 210-221. doi: 10.18196/hi. 5298

Vaugh, Bruce and colleagues. (2009). Terrorism in Southeast Asia. Congressional Research Service, 1-30

Walden, Max. (2017). Phlippines Most Affected by Terrorism in Asia Pacific. https://asiancorrespondent.com/2017/11/phili ppines-terrorism-asiapacific/\#zvuwpiCiSRE28ZIP.97 [Accessed June, 1, 2018]

Yeo, Mike. (2017). Malaysia, Indonesia and Philippines target ISIS in Trilateral Air Patrols.

https://www.defensenews.com/naval/2017/10 /13/malaysia-indonesia-and-philippinestarget-isis-in-trilateral-air-patrols/. [Accessed July, 25, 2018] 